Tersedia online di: http://ejournal-balitbang.kkp.go.id/index.php/JP
e-mail:jurnalpari@gmail.com
JURNAL PARI
Volume 3 Nomor 2 Desember 2017
p-ISSN: 2502-0730
e-ISSN : 2549-0133

\title{
PERTUMBUHAN ARTIKEL PENELITIAN KELAUTAN DAN PERIKANAN DI INDONESIA MELALUI OJS : SEBUAH ANALISIS BIBLIOMETRIK
}

Growth Of Marine And Fisheries Research Articles In Indonesia Through Ojs :A Bibliometric Analysis

\section{SYARIANAH}

Balai Riset Perikanan Budidaya Air Payau dan Penyuluhan Perikanan

Diterima tanggal : 23 Agustus 2017 diterima setelah perbaikan : 16 Oktober 2017 disetujui terbit : 28 November 2017

\begin{abstract}
ABSTRAK
Untuk mengetahui pertumbuhan artikel Kelautan dan Perikanan dilakukan analisis jurnal ilmiah penelitian pada Badan Riset dan Sumberdaya Manusia Kelautan dan Perikanan (BRSDM) yang dipublikasikan melalui Open Journal System (OJS). Dengan menggunakan metode analisis bibliometrik diperoleh hasil bahwa pertumbuhan artikel penelitian rata-rata hanya $-0.01 \%$ setiap tahun. Pola penulisan dengan tiga orang paling tinggi yaitu $807(37.45 \%)$ artikel, sedang terendah pola penulisan lebih dari enam orang yaitu $15(0.7 \%)$. Pertumbuhan rata rata penulis per artikel (RPPA) ditemukan 2.85 dan produktivitas per penulis (PPP) 0.35. Untuk tingkat kolaborasi penulis ditemukan berkisar $0.86-$ 0.94 dengan nilai rata-rata sebesar 0.91. Sedang Publikasi paling produktif adalah Prosiding Forum Innovasi Teknologi Akuakultur yang menghasilkan sebanyak 719 (33.36\%) artikel. Untuk jurnal ilmiah hasil penelitian yang paling produktif adalah Jurnal Riset Akuakultur dengan jumlah publikasi sebanyak 235 (10.90\%) artikel.
\end{abstract}

Kata Kunci : Pertumbuhan Artikel, Produktivitas Peneliti, Analisis Biblimetrik, Onlie Journal System

\section{ABSTRACT}

In order to understand the growth of marine and fisheries article, it has been conducted the analysis of scientific research journals at the Agency for Research and Human Resources Marine and Fisheries (BRSDM) which has been published through the Open Journal System (OJS). By using bibliometric analysis method, it is found that the average research article growth is only $-0.01 \%$ every year. The writing pattern with the highest three persons is 807 (37.45\%) of the article, while the lowest writing pattern is more than six people, namely 15 (0.7\%). The author's average growth per article (RPPA) was found 2.85 and productivity per author (PPP) 0.35. For the writer's level of collaboration found ranged from 0.86 to 0.94 with an average value of 0.91 . The most productive publication is Proceeding Forum Innovation of Aquaculture Technology which produces 719 (33.36\%) articles. For scientific journals, the most productive is the Journal of Aquaculture Research with the number of publications is 235 (10.90\%) articles.

Keywords: Growth Articles, Researcher Productivity, Biblimetric Analysis, Onlie Journal System 


\section{PENDAHULUAN}

Tugas utama dari seorang peneliti adalah mempublikasikan hasil penelitianya. Bagi seorang dosen atau peneliti publikasi adalah suatu hal yang sangat penting, dan yang perlu diingat juga bahwa suatu penelitian belum selesai sebelum hasilnya dipublikasikan, dan salah satu media publikasi ilmiah yang paling terkenal adalah jurnal (Muchlisin, 2013). Tujuan publikasi ilmiah ini antara lain adalah untuk penyebarluasan hasil penelitian, mengembangkan IPTEK, meningkatkan reputasi, prestasi dan prestise si penulis dan lembaga dimana si penulis berada (Rifai, 2012). Sedangkan fungsi jurnal ilmiah adalah sebagai media registrasi, diseminasi, pengarsipan dan sertifikasi hasil-hasil penelitian atau dengan kata lain sebagai jembatan antara penulis dan pembaca. Oleh karena itu menurut Anto Satriyo Nugroho (2004) bahwa seorang peneliti dituntut untuk rajin mengikuti perkembangan teknologi di bidangnya. Sumber utama adalah jurnal ilmiah, yang jumlahnya ribuan dan diterbitkan di berbagai bidang. Akan tetapi akses terhadap literatur ilmiah memiliki keterbatasan. Tidak semua perpustakaan berlangganan jurnal ilmiah dalam versi cetak, yang cukup lengkap dan memenuhi kebutuhan peneliti. Dalam hal ini keberadaan digital library merupakan solusi yang sangat membantu seorang peneliti untuk menemukan sumber informasi yang diperlukannya.

Penerbitan jurnal ilmiah sangat penting untuk publikasi hasil penelitian kepada masyarakat di seluruh dunia, terutama komunitas peneliti sesuai bidangnya. Semakin banyak pembaca, maka sitasi atas artikel yang dihasilkan dalam jurnal ilmiah akan semakin tinggi. Laju perkembangan jurnal selama kurun waktu 10 tahun mulai dari 2003 hingga 2012 mengalami nilai kenaikan ratarata 119.235 artikel tiap tahunnya (Directory of Open Access Journals: 2014). Laju perkembangan jurnal biasanya berbanding lurus dengan laju perkembangan ilmu pengetahuan dan teknologi. Penerbitan jurnal secara cetak memerlukan waktu panjang dalam proses penyuntingan, penelaahan dan paling utama adalah mahalnya biaya pencetakan yang mengakibatkan terbatasnya distribusi jurnal ilmiah. Untuk mempercepat proses pengiriman naskah submission, penyuntingan (editing) dan penelaahan (review) maka jurnal perlu diterbitkan dalam bentuk online. Perubahan paradigma penerbitan jurnal dari cetak menjadi online harus dipersiapkan dengan baik khususnya dari sisi tata kelola (manajemen), sehingga jurnal yang diterbitkan sesuai dengan standar penerbitan jurnal secara online baik nasional maupun internasional. Atas dasar itulah, pengelolaan jurnal ilmiah online harus dikelola dengan serius dan profesional.

Para IImuan membutuhkan sarana untuk mempublikasikan karya baru dari jurnal yang berkomitmen untuk membuka akses ilmu pengetahuan. Dan untuk itulah OJS hadir untuk membantu publikasi jurnal ilmiah yang dipilih sebagai sebuah transisi untuk membuka akses riset dan teknologi yang ada (Budapest Open Access Initiative, 2002). Jika bahasa tertulis adalah penanda peradaban sebuah bangsa. Maka publikasi ilmiah adalah tanda kemajuan olah pikirnya. Namun rasio publikasi ilmiah per akademisi Indonesia yang masih rendah tidak serta-merta menadakan rendahnya output olah pikir bangsa ini. Tentu patut kita sayangkan ketika faktor ekonomilah yang membuat ciut nyali para pengelola publikasi ilmiah yang berakibat lambannya perkembangan dunia akademis Indonesia terutama publikasi ilmiah. Kini universitas, pusat studi, atau lembaga riset yang ingin menerbikan publikasi ilmiahnya dengan efisien bisa menggunakan OJS sebagai satu alternative terbaik.

Untuk mengetahui pertumbuhan artikel Kelautan dan Perikanan dilakukan analisis jurnal ilmiah peneliti pada Badan Riset dan Sumberdaya Manusia Kelautan dan Perikanan (BRSDM) yang dipublikasikan melalui Open Journal System (OJS). Hasil analisis diharapkan dapat memberi gambaran tentang perkembangan artikel hasil penelitian, produktivitas peneliti, pola penulisan, dan kolaborasi penulis dilingkup Kementerian Kelautan dan Perikanan khususnya di BRSDKP.

\section{TINJAUAN LITERATUR}

The British Standard Institutions memberikan defenisi bibliometrik sebagai kajian penggunaan dokumen dan pola publikasi dengan menerapkan metode matematika danstatistik. Objek utama kajian bibliometrika adalah publikasi penelitian yang diterbitkandalam jurnal ilmiah. Publikasi ini dianggap sebagai media penting dalam komunikasi ilmiah, dan merupakan pengetahuan publik serta arsip umum yang dapat diperoleh dandibaca oleh 
siapapun setiap saat. Perkembangan publikasi jurnal ilmiah saat ini sudah mengalami perubahan dari format tercetak ke format elektronik. Perkembanganperubahan format publikasi ini sangat membantu dalam memperoleh data utama dalam analisis bibliometrik.Bibliometrik mengkaji distribusi publikasi secara kuantitatif terhadap literatur, sehingga bibliometrik dikenal memiliki tiga dalil dasar dalam analisiskuantitatifnya.Sulistiyo (2002) menyatakan bahwa analisis bibliometrika bertujuan untuk menjelaskan proseskomunikasi tertulis, sifat dan arah pengembangan sarana deskriptif penghitungan dan analisis berbagai fasetkomunikasi.

Penerapan kajian bibliometrik pada jurnal terbagidalam dua jenis, yaitu selain bersifat evaluatif, juga bersifat deskriptif. Kajian deskriptif biasanyamenggambarkan ciri muatan sebuah jurnal, seperti jumlah halaman, frekuensi terbitan, dan jenis bahasadengan tujuan karakteristiknya dapat dimengerti (Pattah, 2013). Purnomowati (2008) menegaskan bahwa bibliometrika dapat digunakan sebagai metode kajian yang bersifat deskriptif, misalnya yang berkaitan dengan kepengarangan, dan bersifat evaluatif misalnya untuk mengkaji penggunaan literatur melalui analisis sitiran berdasarkan pendapat diatas diketahui bahwa tujuan bibliometrika adalalah merancang bangunan sistem, menyempurnakan tingkatefisiensi pengolaan informasi, identifikasi dan enpgukuran, meramalkan kecenderungan penerbitan dan basis pengembangan teoridalam ilmu informasi. Hal ini bisa digunakan sebagai metode kajian yang bersifat deskriptif dan evaluatif

OJS (Open Journal Systems) adalah sistem manajeman konten berbasis web yang dibuat khusus untuk menangani keseluruhan proses manajemen publikasi ilmiah. Mulai dari proses call for paper,peer review, hingga penerbitan dalam bentuk online. OJS dikeluarkan oleh Public Knowledge Project dari Simon Fraser University dan berlisensi GNU General Public License. OJS memudahkan peran pengelola jurnal, editor, reviewer, penulis, dan pembaca.Publikasi artikel jurnal ilmiah melalui OJS merupakan proses publikasi jurnal ilmiah yang dilakukan secara online, mulai dari submit artikel sampai dengan publish jurnal ilmiah. Seluruh proses publikasi dilakukan melalui web jurnal ilmiah (OJS) dengan menggunakan browser internet (InternetExplorer, Google Chrome, Mozilla Firefox, Safari, dan sejenisnya). OJS membantu dalam setiap tahap proses penerbitan naskah (arikel ilmiah), dari kiriman melalui publikasi online dan pengindeksan. Melalui system manajemen,pengindeksan berjalan secara halus dan berbasis penelitian, sera konteksnya tersedia untuk penelitian. Open Journal System berusaa untuk meningkatkan baik kualitas naskah ilmiah peneliti mapupun masyarakat akademisi.

OJS merupakan perangkat lunak open source yang dibuat tersedia secara bebas untuk jurnal di seluruh dunia dengan tujuan untuk membuat akses terbuka penerbitan pilihan yang layak dan lebih untuk jurnal. Dengan akses terbuka dapat meningkatkan pembaca jurnal serta kontribusinya terhadap masyarakat dalam skala global. OJS memiliki fitur sebagai berikut:

1. Dapat diinstal dan dikendalikan secara lokal

2. Editor dapat mengatur persyaratan, bagian isi konten, proses review, dll.

3. Tersedia pendaftaran dan pengelolaan semua konten secara online

4. Modul berlangganan dengan pilihan penundaan atau akses terbuka.

5. Pengindeksan komprehensif pada bagian konten dari system global.

6. Tersedia alat pembaca untuk konten, berdasarkan bidang dan pilihan editor.

7. Noifikasi email dan kemampuan komentar untuk pembaca

8. Koneks-sensiif lengkap dengan dukungan bantuan online

\section{METODOLOGI}

Data analisis diambil dari Open Journal System (OJS) Badan Riset dan Sumberdaya Manusia Kelautan dan Perikanan (BRSDMKP) Kementerian Kelautan dan Perikananyang yang dipublikasikan dari tahun 2012 - 2016. Sebanyak 16 judul jurnal ilmiah dan 1 judul Prosiding Seminar Nasional yang menjadi sampel kajian. Metode pengumpulan data dilakukan melalui cara dokumentasi yang diperoleh melalui pemeriksaan dan pencatatan terhadap artikel jurnal ilmiah dan prosiding tersebut. Data yang terkumpul selanjutnya dilakukan verifikasi terhadap nama pengarang dan afiliasi institusinya guna menghindari ketidakkonsistenan dalam penulisan. Kemudian mencatat beberapa komponen jurnal dengan cara mengentri data melalui aplikasi Microsoft Exel, yang terdiri dari 
judul artikel dan jurnal atau prosiding, nama penulis, dan institusi penulis, volume, nomor terbitan, dan tahun jurnal. Data yang terkumpul kemudian dianalisis menggunakan pendekatan bibliometrik yang meliputi:

a. Pertumbuhan Artikel Penelitian BRSDM Kelautan dan Perikanan

b. Pola kepengarangan artikel

c. Produktivitas penulis

d. Tingkat kolaborasi penulis

e. Jurnal BRSDMKP paling produktif

Data yang terkumpul diolah, disusun, dan dihimpun serta dilakukan pengamatan untuk keperluan pembahasan dalam bentuk tabel dan grafik serta interpretasi secara deskriptif.

\section{ANALISIS DAN PEMBAHASAN}

\section{a. Pertumbuhan Artikel}

Sebanyak 2155 jumlah artikel hasil penelitian di publikasikan melalui OJS BRSDM Kementerian Kelautan dan Perikanan, yang terdiri dari 16 judul jurnal ilmiah dan 1 judul prosiding seminar nasional. Untuk menghitung pertumbuhan artikel penelitian, digunakan rumus sebagai berikut (Barik, N. dan Jena, P., 2014) :

$$
\mathrm{R}=\frac{\mathrm{Pp}^{1 / 4}}{\mathrm{Po}}-1 * 100
$$

Dimana :

$R=$ Pertumbuhan Hasil Penelitian Tahunan di \%

$\mathrm{Pp}=$ Publikasi Hadir

Po $=$ Publikasi Asli

$\mathrm{N}=$ Interval antara Pp dan Po

Tabel 1: Pertumbuhan Artikel Penelitian Kementerian Kelautan dan Perikanan setiap tahun
Pada Tabel 1 menggambarkan bahwa selama periode tahun 2012 sampai 2016 jumlah artikel yang dipublikasikan paling tinggi pada tahun 2015 yaitu sebanyak $462(21.44 \%)$ artikel, diikuti tahun 2013 sebanyak $446(20.70 \%)$ artikel. Kemudian di tahun 2012 sebanyak 434 (20.14\%) arikel. Angka terendah yaitu pada tahun 2016 hanya mempublikasikan 396 (18.19\%) artikel. Dari data tersebut menggambarkan pertumbuhan artikel setiap tahun tidak tetap, karena pada tahun 2014 terjadi pertumbuhan negatif terhadap jumlah artikel yang dipublikasikan sebesar $-0.99 \%$ dan tahun 2016 sebesar $-2.01 \%$. Sehingga dari tabel 1 menunjukkan bahwa pertumbuhan artikel pada publikasi OJS BRSDMKP rata-rata hanya $-0.01 \%$ setiap tahun.

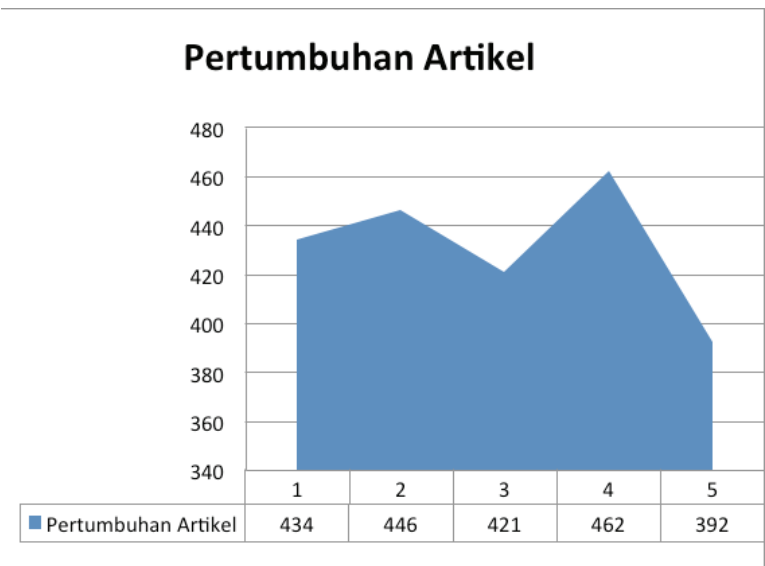

Gambar I: Pertumbuhan publikasi penelitian Kemenerian Kelautan setiap Tahun

\section{b. Pola Penulisan Artikel}

Pada Tabel 2 menguraikan7 pola penulisan artikel yang berkontribusi selama tahun 2012 2016. Jumlah artikel yang disumbangkan oleh masing-masing kategori pada pola penulisan yang telah didistribusikan memperlihatkan bahwapola penulisan tiga orang mendominasi dengan nilai tertinggi sebanyak 807 (37.45\%) arikel,

\begin{tabular}{|c|c|c|c|}
\hline Tahun & Jumlah Publikasi & Persentase & Pertumbuhan Pubikasi setiap Tahun (\%) \\
\hline 2012 & 434 & 20.14 & - \\
\hline 2013 & 446 & 20.70 & 1.37 \\
\hline 2014 & 421 & 19.54 & -0.99 \\
\hline 2015 & 462 & 21.44 & 1.58 \\
\hline 2016 & 392 & 18.19 & -2.01 \\
\hline & 2155 & 100.00 & $\mathbf{- 0 . 0 1}$ (rata-rata) \\
\hline
\end{tabular}


diikuti pola penulisan dua orang dengan jumlah $655(30.39 \%)$ artikel. Pola penulisan empat menduduki peringkat ketiga yaitu sebanyak 330 (15.31) artikel, diikuti penulis tunggal sebanyak $195(9.05 \%)$ artikel. Untuk pola penulisanlima orang berjumlah 126 (5.85\%) artikel, sedangpola penulisanenam orang hanya 29 (1.355) artikel dan terdapat $15(0.7 \%)$ artikel yang memiliki penulis lebih dari enam orang. Dari data tersebut menunjukkan bahwa sebagian besar artikel yang ditebitkan melalui OJS merupakan hasil penulisan ganda atau karya kolaborasi.

Peneliti dalam membuat karya tulis ilmiah salah satu tujuannya selain publikasi hasil penelitian, yaitu mendapatkan angka kredit dalam jabatan fungsional peneliti. Ada kriteria penilaian berdasarkan Juknis Peneliti bahwa pembagian angka kredit untuk karya tulis ilmiah salah satu penilaiannya adalah jumlah penulis, dimana ada perbedaan nilai antara penulis pertama (firts author) dengan penulis kedua, ketiga dan seterusnya.

\section{c. Produktivitas Penulis}

Produktivitas penulis didefinisikan sebagai perbandingan antara hasil yang dicapai (jumlah artikel) dengan seluruh sumber daya yang digunakan (jumlah penulis). Tingkat produktivitas penulis dihitung untuk mengetahui lebih detail jumlah penulis yang mempublikasikan artikelnya. Pada Tabel 3 menggambarkan produktivitas penulis artikel kelautan dan perikanan setiap tahun yang dipublikasikan melalui OJS BRSDMKP dari tahun 2012-2016. Hasil Analisis menunjukkan bahwa selama 5 tahun ditemukan 6145 penulis telah memberikan kontribusi sebanyak 2155 artikel. Perkembangan jumlah penulis dan jumlah artikel setiap tahun berkisar 392 sampai 462 artikel dan 1169 sampai 1345 penulis, dengan kisaran produktivitas penulis 2.73 sampai 2.98 . Sehingga ditemukan bahwa rata-rata penulis per artikel (RPPA) sebanyak 2.85 dan produktivitas per penulis (PPP) sebanyak 0.35. Hasil tersebut lebih tinggi dibanding perhitungan prouktivitas peneliti lingkup P4B yang menghasilkan 0.97 atau rata 0.19 per tahun Syarianah (2016).Jika dibandingkan dengan jumlah produktivitas peneliti Balitbang Pertanian tahun 2004 - 2006 masih tergolong rendah yaitu berkisar $0.22-0.93$ atau rata-rata 0.58 artikel per tahun Rufaidah (2010).

Tabel 3. Produktivitas Penulis

\begin{tabular}{|c|c|c|c|c|}
\hline \multirow{2}{*}{ Tahun } & \multicolumn{2}{|c|}{ Produktivitas Penulis } & \multirow{2}{*}{ Total } \\
\cline { 2 - 4 } & $\begin{array}{c}\text { Total } \\
\text { Artikel }\end{array}$ & $\begin{array}{c}\text { Total } \\
\text { Penulis }\end{array}$ & $\begin{array}{c}\text { Total } \\
\text { RPP }\end{array}$ & PPP \\
\hline 2012 & 421 & 1211 & 2.88 & 0.35 \\
\hline 2013 & 462 & 1345 & 2.91 & 0.34 \\
\hline 2014 & 392 & 1169 & 2.98 & 0.34 \\
\hline 2015 & 434 & 1201 & 2.77 & 0.36 \\
\hline 2016 & 446 & 1219 & 2.73 & 0.37 \\
\hline Total & 2155 & 6145 & 2.85 & 0.35 \\
\hline
\end{tabular}

\section{d. Tingkat Kolaborasi Penulis}

Tingkat kolaborasi penulis, dianalisis kolaborasi yang menonjol dan menunjukkan trend publikasi pola penulis tunggal dan gabungan. Untuk menhitung tingkat kolaborasi penulis digunakan rumus Subrahmanyan (1983) sebagai berikut :

Tabel 2 : Pola penulisan yang digunakan dalam artikel

\begin{tabular}{|c|c|c|c|c|c|c|c|cr|}
\hline \multirow{2}{*}{ Tahun } & \multicolumn{6}{|c|}{ Pola penulisan yang digunakan dalam artikel } & \multicolumn{2}{|}{ Total } \\
\cline { 2 - 10 } & Satu & Dua & Tiga & Empat & Lima & Enam & >Enam & \multicolumn{2}{|c|}{} \\
\hline 2012 & 59 & 122 & 154 & 71 & 19 & 7 & 2 & 434 & $(20.14)$ \\
\hline 2013 & 50 & 148 & 162 & 58 & 20 & 4 & 4 & 446 & $(20.70)$ \\
\hline 2014 & 33 & 137 & 151 & 64 & 25 & 7 & 4 & 421 & $(19.54)$ \\
\hline 2015 & 28 & 143 & 183 & 67 & 35 & 3 & 3 & 462 & $(21.44)$ \\
\hline 2016 & 25 & 105 & 157 & 70 & 27 & 8 & & 392 & $(18.19)$ \\
\hline Jumlah & 195 & 655 & 807 & 330 & 126 & 29 & 15 & 2155 & \\
\hline 195 & $(9.05)$ & $(30.39)$ & $(37.45)$ & $(15.31)$ & $(5.85)$ & $(1.35)$ & $(0.7)$ & $(100)$ & \\
\hline
\end{tabular}




$$
C=\frac{\mathrm{Nm}}{(\mathrm{Nm}+\mathrm{Ns})}
$$

Dimana :

C = tingkat kolaborasi penulis dalam suatu disiplin ilmu, dengan nilai berada pada interval 0 sampai 1

$\mathrm{Nm}=$ jumlah penulis ganda (lebih dari satu)

Ns $=$ jumlah penulis tunggal

Tabel 5 berikut menunjukkan aplikasi dari persamaan diatas dalam menghitung tingkat kolaborasi penulis di tahun yang berbeda. Pada tabel tersebut menggambarkan kolaborasi penulis selama 5 tahun berkisar 0.86 - 0.94. Dari data tersebut terlihat adanya peningkatan jumlah kolaborasi penulis dari tahun 2012 ke tahun 2015. Sedangkanpeningkatan jumlah kolaborasi tidak terjadi di tahun 2015 ke tahun 2016. Sehingga ditemukan nilai tingkat kolaborasi penulis ratarata sebesar 0.91 .

Tabel 5. Tingkat kolaborasi penulis

\begin{tabular}{|c|c|c|c|c|}
\hline \multirow{2}{*}{ Tahun } & \multicolumn{4}{|c|}{ Tingkat Kolaborasi Penulis } \\
\cline { 2 - 5 } & $\begin{array}{c}\text { Penulis } \\
\text { tunggal } \\
\text { (Ns) }\end{array}$ & $\begin{array}{c}\text { Beberapa } \\
\text { Penulis } \\
\text { (Nm) }\end{array}$ & $\begin{array}{c}\text { (Ns + } \\
\text { Nm) }\end{array}$ & $\begin{array}{c}\text { Derajat } \\
\text { Kolaborasi }\end{array}$ \\
\hline 2012 & 59 & 375 & 434 & 0.86 \\
\hline 2013 & 50 & 396 & 446 & 0.89 \\
\hline 2014 & 33 & 388 & 421 & 0.92 \\
\hline 2015 & 28 & 434 & 462 & 0.94 \\
\hline 2016 & 25 & 367 & 392 & 0.94 \\
\hline & 195 & 1960 & 2155 & (mean) \\
\hline
\end{tabular}

\section{e. Jurnal Paling Produktif}

Jurnal paling produktif pada tabel 6 menunjukkan bahwa dari tujuh belas judul publikasi ilmiah, terbitan Prosiding Forum Innovasi Teknologi Akuakultur (FITA) menduduki peringkat paling tinggi dalam memproduksi artikel ilmiah yaitu sebanyak 719 (33.36\%) artikel. Sedangkan untuk kelompok jurnal ilmiah publikasi artikel paling tinggi pada Jurnal Riset Akuakultur yaitu sebanyak 235 (10.90\%) artikel. Tiga Jurnal ilmiah menghasilkan lebih dari seratus artikel yaitu Jurnal Penelitian Perikanan Indonesia 148 (6.87\%) artikel, Bulletin Litkayasa Akuakultur $146(6.77 \%)$ artikel dan Bawal Widya Riset Perikanan Tangkap sebanyak 110 (5.10\%) artikel.
Selanjunya ada delapan jurnal ilmiah yang menghasilkan 50 sampai 100 artikel, masingmasing Jurnal Sosial Ekonomi Kelautan dan Perikanan, Indonesian Aquaculture Journal, Media Akuakultur, Jurnal Pasca Panen dan Bioteknologi Kelautan dan Perikanan, Squalen Bulletin of Marine and Fisheries Postharvest and Biotechnology, Indonesian Fisheries Research Journal, Jurnal Kebijakan Perikanan Indonesia, dan Jurnal Kebijakan Sosial Ekonomi Kelautan dan Perikanan. Selain itu ada tiga judul Jurnal ilmiah yang menghasilkan dibawah 50artikel selama lima tahun yaitu : Buletin IImiah Marina Sosial Ekonomi Kelautan dan Perikanan, Jurnal Pari, dan Jurnal Kelautan Nasional.

Dari uraian diatas terlihat bahwa Prosiding Forum Innovasi Teknologi Akuakultur (FITA) dan Jurnal Riset Akuakultur (JRA) yang paling produktif ini karena dalam lingkup P4B terdapat suatu kebijakan pimpinan secara berjenjang bahwa semua peneliti wajib memaparkan hasil penelitiannya dalam pertemuan FITA yang dimulai sejak tahun 2009 sampai terakhir tahun 2016. Kewajiban tersebut dianggap sebagai wujud pertanggung jawaban pelaksanaan penelitian di masing-masing satker lingkup Pusat Penelitian dan Pengembangan Perikanan Budidaya (P4B). Selain itu, setiap Satker juga mendukung kebijakan tersebut dengan mengalokasikan anggaran perjalan untuk pertemuan FITA. Salah satu satker yaitu Balai Riset Perikanan Budidaya Air Payau dan Penyuluhan Perikanan (BRPBAP3) Maros, membuat kebijakan internal bahwa setiap peneliti wajib ikut dengan syarat mempunyai karya tulis ilmiah (KTI) yang dipresentasikan baik oral maupun poster. Sementara itu, jurnal paling produktif yaitu JRA karena adanya kebijakan dan monitoring ketat dari pengelola jurnal yang terus memonitor agar setiap satker mendorong peneliti untuk memasukkan (upload) KTI. Hal ini pun didukung oleh setiap satker dengan menetapkan setiap kegiatan penelitian mempunyai target indikator berupa $\mathrm{KTI}$ yang dimuat di jurnal salah satunya JRA.

\section{KESIMPULAN}

Hasil analisispertumbuhan artikel Kelauan dan Perikanan yang dipublikasikan melalui Open Journal System (OJS) menunjukkan bahwa pertumbuhan artikel rata-rata hanya $-0.01 \%$ 
Tabel 6. Jurnal BRSDMKP Paling Produktif

\begin{tabular}{|c|l|c|c|c|c|}
\hline \multirow{2}{*}{ Peringkat } & \multicolumn{1}{|c|}{ Kontribusi Artikel } & \multirow{2}{*}{$\begin{array}{c}\text { Jumlah } \\
\text { Artikel }\end{array}$} & $\begin{array}{c}\text { Persentase } \\
\text { (\%) }\end{array}$ & $\begin{array}{c}\text { Kumlah } \\
\text { Artikel }\end{array}$ & $\begin{array}{c}\text { Persentase } \\
\text { (\%) }\end{array}$ \\
\hline 1 & Forum Inovasi Teknologi Akuakultur & 719 & 33.36 & 719 & 33.36 \\
\hline 2 & Jurnal Riset Akuakultur & 235 & 10.90 & 954 & 44.27 \\
\hline 3 & Jurnal Penelitian Perikanan Indonesia & 148 & 6.87 & 1102 & 51.14 \\
\hline 4 & Bulletin Litkayasa Akuakultur & 146 & 6.77 & 1248 & 57.91 \\
\hline 5 & BAWAL Widya Riset Perikanan Tangkap & 110 & 5.10 & 1358 & 63.02 \\
\hline 6 & Buletin Teknik Litkayasa Akuakultur & 106 & 4.92 & 1464 & 67.94 \\
\hline 7 & $\begin{array}{l}\text { Jurnal Sosial Ekonomi Kelautan dan } \\
\text { Perikanan }\end{array}$ & 96 & 4.45 & 1560 & 72.39 \\
\hline 8 & Indonesian Aquaculture Journal & 92 & 4.27 & 1652 & 76.66 \\
\hline 9 & Media Akuakultur & 88 & 4.08 & 1740 & 84.69 \\
\hline 10 & $\begin{array}{l}\text { Jurnal Pasca Panen dan Bioteknologi } \\
\text { Kelautan dan Perikanan }\end{array}$ & 85 & 3.94 & 1825 & 84.69 \\
\hline 11 & $\begin{array}{l}\text { Squalen Bulletin of Marine and Fisheries } \\
\text { Postharvest and Biotechnology }\end{array}$ & 75 & 3.48 & 1900 & 88.17 \\
\hline 12 & Indonesian Fisheries Research Journal & 66 & 3.06 & 1966 & 91.23 \\
\hline 13 & Jurnal Kebijakan Perikanan Indonesia & 61 & 2.83 & 2027 & 94.06 \\
\hline 14 & $\begin{array}{l}\text { Jurnal Kebijakan Sosial Ekonomi } \\
\text { Kelautan dan Perikanan }\end{array}$ & 60 & 2.78 & 2087 & 96.84 \\
\hline 15 & $\begin{array}{l}\text { Buletin IImiah Marina Sosial Ekonomi } \\
\text { Kelautan dan Perikanan }\end{array}$ & 45 & 2.09 & 2132 & 98.93 \\
\hline 16 & Jurnal Pari & 19 & 0.88 & 2151 & 99.81 \\
\hline 17 & Jurnal Kelautan Nasional & 4 & 0.19 & 2155 & 100.00 \\
\hline & Jumlah & 100.00 & & \\
\hline
\end{tabular}

setiap tahun. Pola penulisan tiga orang tertinggi sebanyak $807(37.45 \%)$ sedang terendah pola penulisan lebi dari enam orang yaitu sebanyak15 $(0.7 \%)$. Untuk Pertumbuhan rata rata penulis per artikel (RPPA) ditemukan 2.85 dan produktivitas per penulis (PPP) 0.35 . Tingkat kolaborasi penulis berkisar $0.86-0.94$ dengan nilai rata-rata sebesar 0.91. Publikasi paling produktif adalah Prosiding Forum Innovasi Teknologi Akuakultur yaitu sebanyak 719 (33.36\%) artikel. Sedang jurnal ilmiah yang paling produktif adalah Jurnal Riset Akuakultur yaitu dengan jumlah publikasi sebanyak 235 (10.90\%) artikel.

\section{REFERENSI}

Anto Satriyo Nugroho, 2004. Berita IPTEK: Iptek dan media online Merangsang Pertumbuhan Iptekdengan InformasiOnline. http://jurnal.lipi. go.id/utama. cgi?dukungan\&1097338262\&1

Barik, Nilaranjan and Jena, Pushpanjali, "Growth of LIS Research Articles in India seen through Scopus: A bibliometric analysis" (2014). Library Philosophy and Practice (e-journal). Paper 1133. http://digitalcommons.unl.edu/ libphilprac/1133.

Budapest Open Access Initiative, 2002. https:// en.wikipedia.org/wiki/Budapest_Open_ Access_Initiative.

DOAJ. 2014. "Directory of Open Access Journals." Diakses 1 Mei 2014. http://doaj.org/searc h? source $=\{\% 22$ query $\% 22:\{\% 22$ match all\%22:\{\}\}\}. 
Muchlisin, Z.A. 2013. Menakar Produktifitas Publikasi Internasional Universitas Syiah Kuala "Si Jantong Hatee Rakyat Aceh". https://unsyiah.academia.edu /muchlisinza/ Teaching-Documents.

Pattah, 2013. Pemanfaatan kajian bibliometrika sebagai metode evaluasi dan kajian dalam ilmu perpustakaan dan informasi. Jurnal IImu Perpustakaan dan Informasi Khizanah Al-Hikmh, 1 (1) : 47-57.

Peraturan Kepala Lembaga IImu Pengetahuan Indonesia Nomor 2 Tahun 2014. Tentang Petunjuk Teknis Jabatan Fungsional Peneliti.
Purnomowati, Sri. 2008. Pola Kepengarangan dan Pola Sitiran Tiga Judul Majalah Indonesia Bidang IImu Perpustakaan dan Informasi. Berita Iptek, 42, 125-140.

Rifai, M. 2012. Etika penulisan dan kode etik penulis. Materi pelatihan publikasi artikel ilmiah untuk jurnal internasional. Dirjen Dikti, Jakarta.

Subramanyan, K. 1983. Bibliometrics study of research collaboration;review. J. Inform. Sci. 6(1): 33-38.

Sulistyo-Basuki. 2002. "Bibliometrika, Sainsmetrika Dan Informetrika."Kumpulan makalah kursus bibliometrika. Universitas Indonesia. 